\title{
Remembering Yarrie: An Indigenous Australian and the 1852 Gundagai Flood
}

WARDININGSIH SOERJOHARDJO

$\mathrm{T}$

The township of Gundagai was established on the banks of the Murrumbidgee River, close to a river crossing, in the 1830s. The name Murrumbidgee is said to have derived from an Aboriginal warning 'Mor-unbeed-ja', which means 'a big flood'. ${ }^{1}$ The statistical record indicates that the population in 1851 was 397 in the town and 1019 in the rural districts. ${ }^{2}$ Like other towns in New South Wales, Gundagai possessed a smaller number of Australian born than foreign born inhabitants -622 out of $1313 .{ }^{3}$ In the same year, there were only seven Chinese males in Gundagai. One lived in the town and six lived in the Police District. The number of Aborigines in Gundagai, on the other hand, is unclear. James Gormly remembered that when he first came in 1842 that the 'Blacks were very numerous'. ${ }^{4}$ An annual report made by the Commissioner of Crown 
Land of Cullendina-Lower Murray, William MacKenzie, in 1851, stated that Gundagai's Aborigines, who were categorized as of the Tumut Tribe, consisted of 35 groups. ${ }^{5}$ This record does not tell us the number of Aborigines in each group, but the fact that there were 35 groups does suggest a numerous population.

In 1852 a most tragic flood occurred in the place, in which some indigenous Australians, Yarrie ${ }^{6}$ and his friends, rescued White men with a bark canoe. The large death toll and property lost drew the attention of the whole colony to the town. Large numbers of people were drowned, public buildings were swept away and much private property was damaged. Estimates of the number of people drowned differed. Parliamentary papers, for example, reported that 75 persons drowned in the flood. ${ }^{7}$ The Burial Registers of the Anglican Church of Yass recorded the burials of 73 Anglicans, ${ }^{8}$ and according to an Anglican clergyman, Rev C. F. Brigstocke, eight Catholics also drowned. ${ }^{9}$ Lachlan Ross, an eyewitness, noted that almost 100 people perished. ${ }^{10}$ Parliamentary papers recorded that landed property, goods and chattels destroyed, damaged or swept away by the great flood were valued at about $£ 8126 .{ }^{11}$

The earlier flood which had occurred in 1844 should have been sufficient warning to all inhabitants that, sooner or later, Gundagai's position was extremely dangerous. They also had the visible marks of former floods showing the water level had reached an even higher point than that of the 1844 flood. There was, furthermore, testimony of old Aborigines that floods had occurred which had covered the tops of the large gum trees. ${ }^{12}$ Despite these warnings, in the words of a contemporary newspaper, 'people continued adding to their purchases in the town, and to the size of their buildings, and consequently adding day by day to their ruin. ${ }^{13}$ The Government put up allotments for sale on the higher ground but few of these found Purchasers. People still preferred the lower ground, the bed of the river, even though their lives were in peril. ${ }^{14}$

Yarrie, who came from Brungle in the Gundagai Police District, played an important role in rescuing many town people. He worked as shepherd at Nangus station which belonged to the Gormly family. ${ }^{15}$ James Gormly, who was a child at the time of the flood, remembered Yarrie 'on his knees, crouched in the bottom of his frail canoe which was liable to be upset by the current at any moment.' ${ }^{16}$ Yarrie 'was willing to run any risk to give assistance'. Although his 
canoe would only carry two light persons at once, he rescued the wife and children of a man named Reardon. ${ }^{17} \mathrm{Mr}$ Reardon was away at the Bendigo gold diggings when the flood occurred and only heard later of Yarrie's deeds.

Richard T. Kennedy recorded that Yarrie also rescued the wife and daughter of one of the town's leading citizens, surgeon $\mathrm{Dr}$ Davison, taking them off the roof of their house..$^{18}$ Another important town citizen rescued by Yarrie was the puntkeeper and surgeon, Dr John Spencer, who 'after swimming three quarters of a mile, got on a tree on Stucky Island, where he remained naked, until noon next day, when he was got off by a black named Yarra. ${ }^{19}$ Yet another important business family to be rescued by Yarrie was the Turnbull family 'after intermidable hours of dreadful experience. ${ }^{20}$ Altogether Yarrie rescued 49 people from rooftops and trees. ${ }^{21}$

The Sydney Morning Herald of 15 July 1852 also recorded that Jackey, who worked for Mr. Joseph Andrews, 'afforded in this respect the most valuable assistance, saving a great many lives'. An eyewitness of the flood, Lachlan Ross, who was at that time on his way to the gold rush, stated that what the Aborigines had done was 'a most difficult task... The fellows (Black if you like) did splendid service. $^{22}$

The heroic deeds of Yarrie, Jackey and two other unknown Aborigines left a deep and lasting memory right up to the present. There are numerous ways in which memories are constructed, reproduced and circulated in the culture. Nancy Wood's Vectors of Memory: Legacies of Memory in Post War Europe investigates conduits of memorial activity in the twentieth century. ${ }^{23}$ Wood observed:

Memory is decidedly in fashion. Whether attention is focused on the so-called repressed memories' of the abused individual, or on the 'black holes' in a nation's recollection of its past, the topic of memory has become a compelling preoccupation of academics and non-academics alike. ${ }^{24}$

Unlike Wood's view of the 'repressed memory of the abused individual', the case of memories of Yarrie's heroism during the 1852 Gundagai tragic flood, embodied in the mind of the white flood survivors, who gave their testimonials, were obviously good memories, portraying a highly respect towards such a heroism demonstrated by the indigenous Australians. These can be delineated 
from memories of the flood expressed by James Gormly, the Reardons, Richard T. Kennedy, surgeon Dr. Davison, the punt keeper and surgeon Dr John Spencer, Turnbul and Joseph Andrews, who, along with their families and friends were saved by Yarrie and Jackey. Such memories simultaneously derived from individuals experiencing the flood and were strengthened by an eyewitness of the flood, Lachlan Ross. Wood argues that 'since memory arises from lived experience only individual can remember, the notion of "collective memory" allows us to signal some tangible presence of past that can be discern beyond the level of the individual and in specific social milieux.' She also quotes Maurice Halbwachs - the first modern theorist of collective memory - who observed that 'any hard and fast distinction between individual and social memory is questionable precisely because the "very words and ideas" out of which "autobiographical memory" emerges are appropriated from a social milieu. ${ }^{25}$ Halbwachs confirms that the meaning of individual memories had to be sought not only in the recesses of the unconscious, or in the familial nexus whose intimate dramas it inscribed, but with reference to the social milieux in which the child's life was always and already immersed.' He therefore notes that 'collective memory be conceived as the "social frameworks" [cadres sociaux] onto which such personal recollections were woven', though 'further specification in the light of a tendency to see this process as one where amorphous residues of the past, conjured by individuals, are amassed into shared imagery until they receive social expression. ${ }^{26}$

The individual memory testified by James Gormly derived from his childhood memory of the flood, witnessing Yarrie's hard attempt to save the wife and children of Mr Reardon. Halbwachs suggested that such a memory 'was always and already immersed. ${ }^{27}$ Memories of the past, particularly of the 1852 flood and Yarrie's deeds, awakened by individuals - the flood's survivors and the witnesses were then interwoven with each other, and they gradually accumulated into an imagination, and were finally shared amongst Gundagai citizens until they formally and explicitly became a received social expression. This is indicated by the creation of memorials dedicated to Yarrie either by members of the community or by the Gundagai Historical society. ${ }^{28}$ The flood's survivors and eyewitnes thus became the 'vectors' of memories. ${ }^{29}$ 
When the news of the 1852 flood reached other places in Australia, a range of publications on the flood and the story of Yarrie's heroic deeds appeared in the media almost immediately. This included the Sydney Morning Herald, the Goulburn Herald and The Empire. Following the point made by Wood, I also treat the 1852 Australian media as 'one "vector of memory" - a pre-eminent one, but by no means the only cultural practice that is charge with "anchorage" and representing and transmitting a society's relationship to its past. ${ }^{\prime 30}$ Other forms included memorials, a sundial, sculpture and poems about Yarrie which are currently located at the Gundagai Local Museum. They serve to conjure the past to the present.

\section{REMEMBERING YARRIE}

Bronwyn Batten has written that 'memorials dedicated to events and people of the past are a common feature of Australian landscape' ${ }^{31}$ The memorials presented to Yarrie were indeed created by the white community living in Gundagai. Batten also says that 'the traditional Aboriginal culture did not memorialise events in a way obviously visible to Australia's European colonisers' and 'the majority of memorials around Australia primarily commemorate the lives of men of European origin.' Yarrie, however, is one of a number of exceptions.

Bulbeck has identified at least three distinct types of memorials to the Aboriginal past in Australia. The first concerns the period between 1850 and 1961 in which Aborigines were described in a number of memorials as 'helpers' of explorers or as treacherous natives. Secondly, the period from the 1870s until the 1960s, when memorials were erected to the 'last full blood' or the local 'Aboriginal King' - individuals who were often 'integrated into the local white community'. Thirdly, the most recent phenomenon in the memorialisation of the Aboriginal past is the move to acknowledge whole tribal groups and attempts acknowledge the deeds of ordinary Aboriginal people, the move to acknowledge whole tribal groups, and attempts to acknowledge atrocities that were inflicted on Aboriginal people by white community. ${ }^{32}$ More recently, Hamilton and Ashton have explored the re-emergence of memorialisation of Aboriginal and other pasts in the later half of the twentieth century. ${ }^{33}$ Memorials presented to Yarrie's heroism in the 1852 Gundagai flood 
categorised him as 'a helper' to the 49 white people he rescued not as 'a hero' as suggested by a poem titled 'Yarrie: The Hero of the Tragic Night' published in the Gundagai Independent on 26 June 1925.

A range of various memory 'vectors' have been created by Gundagai community to communicate the past and the present. The first took the form of a poem. James Riley, whose groom and cook had been rescued by Yarrie, wrote 'The calamity of Gundagai' in August 1852. The sixth verse notes:

Again, Australia's able son,

With vigor ply their frail canoe,

Right well hast thou already done,

But much, o much is, still to do. ${ }^{34}$

Yarrie's story was also circulated in local, popular media. The Camperdown Chronicle dated 9 October 1930, for example, carried a short item on him. Headed 'King Yarrie', it observed that:

Yarrie, the blackfellow, or one of the sable heroes who saved many a settler from death on the occasion of the disasterous flood at Gundagai in the long ago, happened to be seated on a bench in the verandah of an innat Adelong Crossing, now Tumblong, when up came the Earl of Belmore, then Governor of the Colony seated on a box with a fine six in hand coach. Yarrie, who was king of the local tribe of aboriginals, went out to the coach and greeted the [Governor]. ${ }^{35}$

The Gundagai Historical Society has commemorated Yarrie's heroism by erecting a plaque in front of the local museum. Unveiled on 5 December 1980, the plaque commemorates the centenary of Yarrie's death. Two decades earlier, in 1960, W. Wallace Horsley whose grandfather, the late Frederick Horsley, who had been rescued by Yarrie, erected in front of his home in Adelong, Gundagai district, a sculpture of Yarrie on his bark canoe. He also named his property 'Yarri'. ${ }^{36}$ 


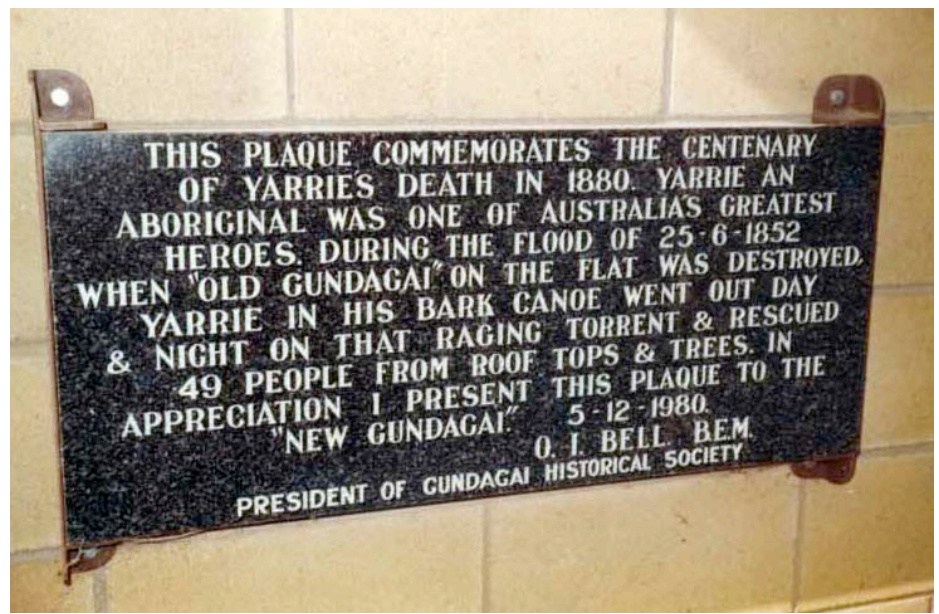

Photograph Wardiningsih Soerjohardjo)

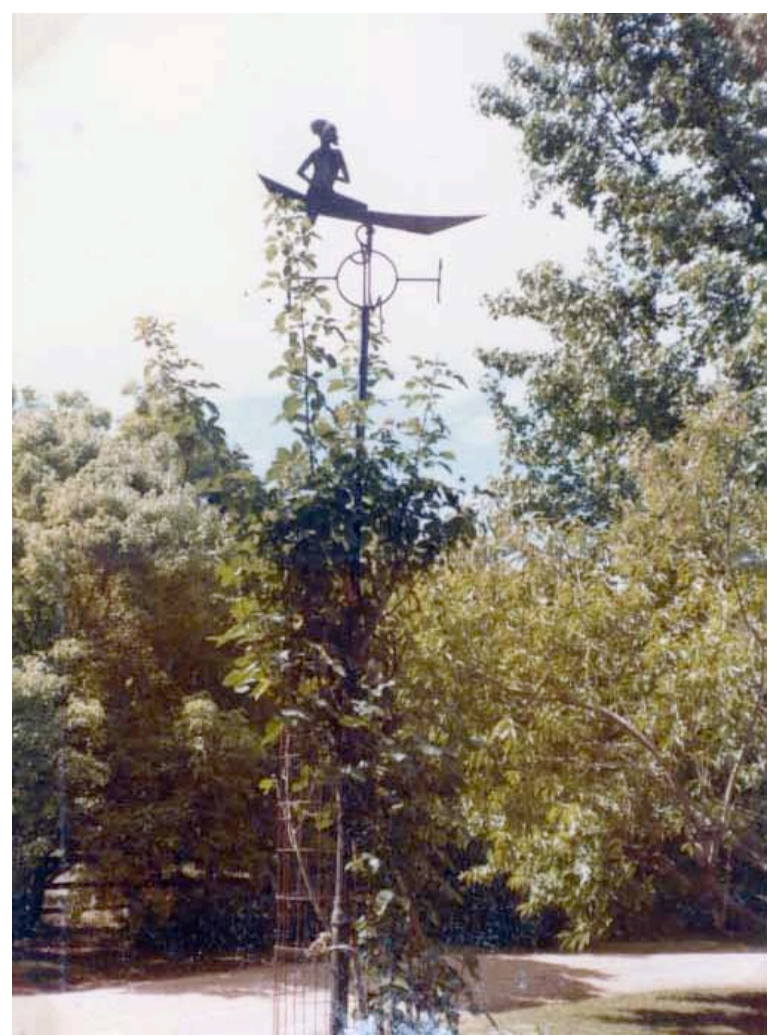

Sculpture of Yarrie, erected in front of the Horsley Family Residence, Adelong Property (Photograph Wardiningsih Soerjohardjo) 


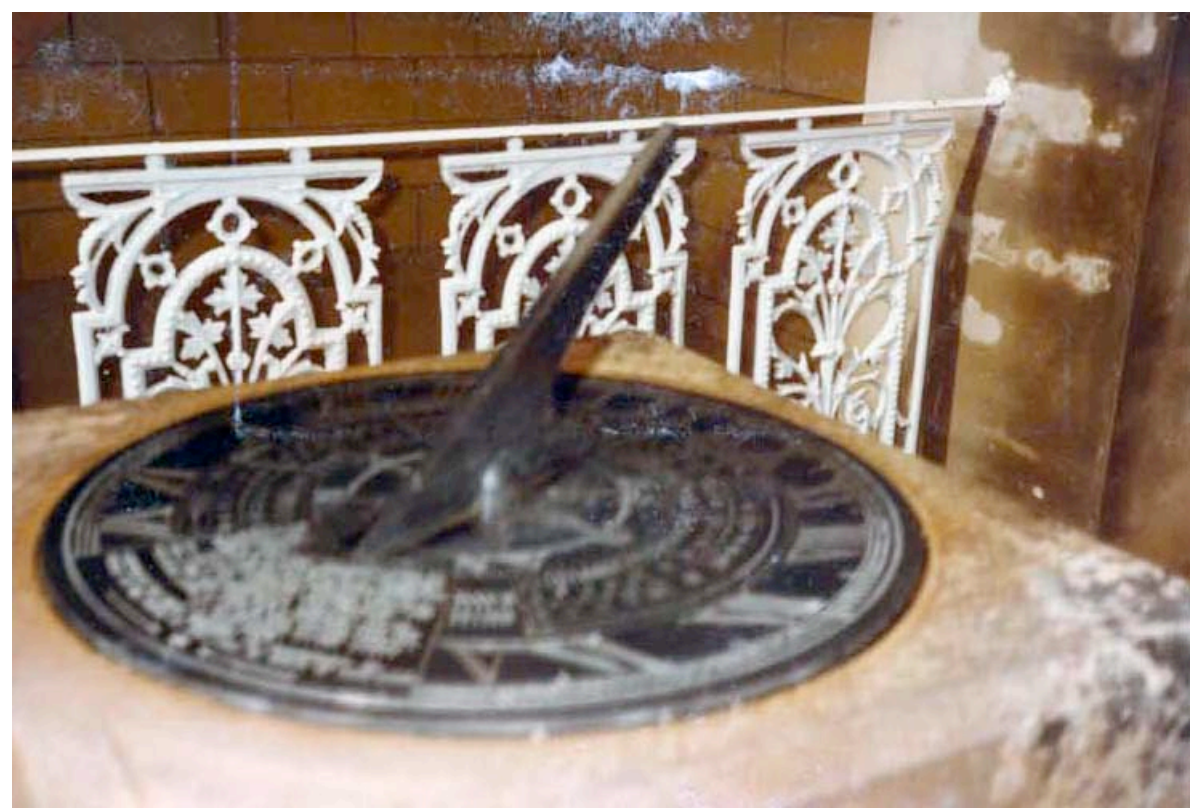

The Sundial was removed from the Gundagai Court House to the front part of the Local Museum, Gundagai (Photograph Wardiningsih Soerjohardjo)

The Horsley family presented a sundial to the town in 1952 which was erected in the Gundagai local museum. The inscription on the sundial says:
THIS SUNDIAL WAS PRESENTED TO GUNDAGAI BY THE HORSLEY OF YABTREE IN MEMORY OF THOSE INHABITANTS WHO LOST THEIR LIVES IN THE DISASTROUS FLOOD ON THE 25TH OF JUNE 1852. ON THAT DATE GUNDAGAI, THEN SITUATED ON THE FLAT, WAS WASHED AWAY AND SEVENTY-TWO RESIDENTS WERE DROWNED.
RICHARD FREDERICK HORSLEY SAVED HIS LIVE BY CLIMBING FROM A FLOATING ROOFTOP INTO A TREE FROM WHICH HE WAS RESCUED THIRTY-SIX HOURS LATER BY AN ABORIGINE NAMED YARRIE IN A BARK CANOE. ACCEPTED BY THE SHIRE PRESIDENT CR. STRIBLEY ON BEHALF OF THE PEOPLE OF GUNDAGAI ON THE 25TH JUNE 1952.

On the centenary of 1852 flood, the Gundagai Independent, reported: 
There were no V.C.'s or George Medals for bravery back in the fifties. If there had been, the great Australian hero Yarrie - would have 'copped the lot. ${ }^{37}$

An unknown versifier wrote with faintly racist overtones:

But on he went and on again,

A Black man, but his heart was white;

Not once to cross that stream in vain

Till barred by darkness of night. ${ }^{38}$

Jackey was also presented with copper medallion by the subscribers to a relief fund in appreciation of his courageous assistance during the flood.$^{39}$ The medallion, on a chain to be worn around the neck as a 'breast-plate', is seven inches long and three inches wide. At the top is a drawing of the flood, with a man perched high up in a tree above the swirling waters, whilst below, in a bark canoe, is an Aborigine rowing towards the stranded settlers. The wording on the medallion reads:

\section{PRESENTED TO JACKEY}

By the subscribers to a relief fund as a reward for his assisting the sufferers during the floods at Gundagai in the $25^{\text {th }}$ June, $1852^{40}$

\section{CONCLUSION}

The Story of Yarrie has been in the memory of Gundagai people for generations. Such a memory has been strengthened by the presence of memorials dedicated to Yarrie during the 1852 flood. The cultural production performed by the memorialisation of Yarrie's role during the 1852 flood was made possible through the activities of the local community, the Gundagai Historical Society, the local museum, local government, prominent citizens and the popular media.

\section{ENDNOTES}

${ }^{1}$ S. H. Roberts, The Squatting Age in Australia 1835-1847, Melbourne University Press, 1935, p5.

${ }^{2}$ The Blue Book 1851.

${ }^{3}$ The 1856 New South Wales Census

${ }^{4}$ James Gormly, In His Reminicences, vol I, Newspaper Cutting, Mitchell Library (ML),

Sydney.

${ }^{5}$ A.J.C.P., Reel 616, p181. 


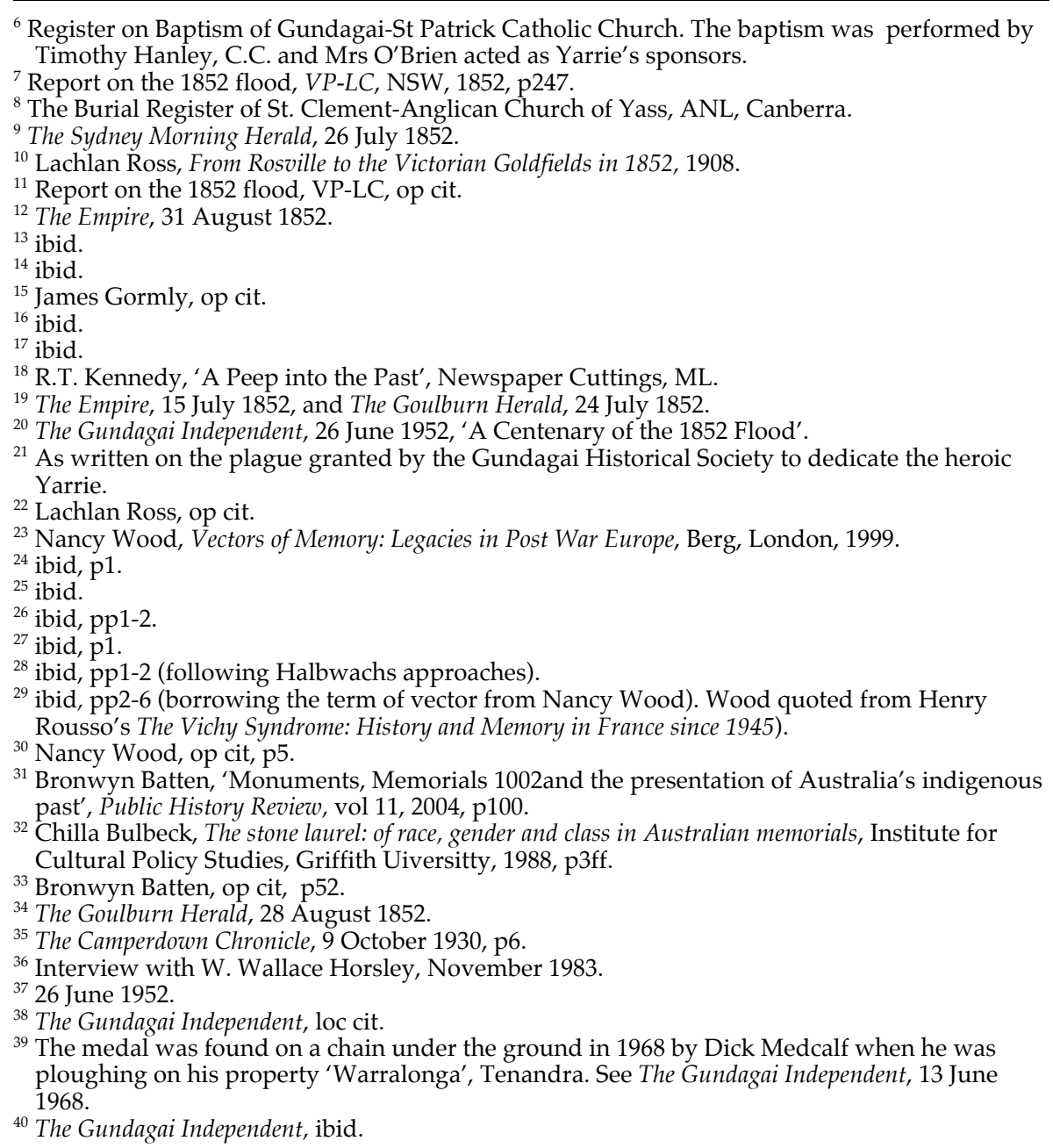

